\title{
Effect of Processing Parameters on the Protective Quality of Electroless Nickel-Phosphorus on Cast Aluminium Alloy
}

\author{
Olawale Olarewaju Ajibola, ${ }^{1,2}$ Daniel Toyin Oloruntoba, ${ }^{1}$ and Benjamin O. Adewuyi ${ }^{1}$ \\ ${ }^{1}$ Department of Metallurgical and Materials Engineering, Federal University of Technology, Akure, Akure 340252, Nigeria \\ ${ }^{2}$ Department of Materials and Metallurgical Engineering, Federal University Oye-Ekiti, Oye-Ekiti 371104, Nigeria \\ Correspondence should be addressed to Olawale Olarewaju Ajibola; olawale.ajibola@fuoye.edu.ng
}

Received 29 June 2015; Revised 7 September 2015; Accepted 20 September 2015

Academic Editor: Menahem Bamberger

Copyright (c) 2015 Olawale Olarewaju Ajibola et al. This is an open access article distributed under the Creative Commons Attribution License, which permits unrestricted use, distribution, and reproduction in any medium, provided the original work is properly cited.

\begin{abstract}
The effects of temperature, $\mathrm{pH}$, and time variations on the protective amount and quality of electroless nickel (EN) deposition on cast aluminium alloy (CAA) substrates were studied. The temperature, $\mathrm{pH}$, and plating time were varied while the surface condition of the substrate was kept constant in acid or alkaline bath. Within solution $\mathrm{pH}$ of 5.0-5.5 range, the best quality is obtained in acid solution $\mathrm{pH}$ of 5.2. At lower $\mathrm{pH}$ (5.0-5.1), good adhesion characterised the EN deposition. Within the range of plating solution $\mathrm{pH}$ of 7.0 to 11.5 , the highest quantity and quality of EN deposition are obtained on CAA substrate in solution $\mathrm{pH}$ of 10.5 . It is characterised with few pores and discontinuous metallic EN film. The quantity of EN deposition is time dependent, whereas the adhesion and brightness are not time controlled. The best fit models were developed from the trends of result data obtained from the experiments. The surface morphologies and the chemical composition of the coating were studied using the Jeol JSM-7600F field emission scanning electron microscope.
\end{abstract}

\section{Introduction}

Electroless plating is a process that does not require electricity before metal deposition is attained from the solution. Electroless plating is an established industrial practice and gained increasing significance at the present time. By such ways both pure metals and alloys can be formed on ferrous and nonferrous materials with enhanced surface characteristics. This is accomplished by applying suitable surface pretreatment processes [1].

The nomenclature, electroless, is a bit ambiguous according to Schlesinger and Paunovic [2]. Even though no external electrodes are present, electric current is engaged. The metal coat is supplied by the metal salt in place of an anode; metal replacement is accomplished either by the addition of salt or by external looping with an anode of the matching metal of higher efficiency than the cathode. Hence, the substrate serves as the cathode, as a substitute of a cathode to reduce the metal, whereas the electrons are supplied by the reducing agent.
The rewards include uniform plating and the ability to coat nonconductive materials $[3,4]$. The ease of simultaneous deposition particulate matters within a matrix of $\mathrm{EN}$ has given birth to the discovery and the development of new composite coatings, which can be made with crystalline and/or amorphous structure having a wide range of compositions $[5,6]$. Electroless Ni-P coatings were plated on aluminium alloy surface and the effect of posttreatment was studied on the wear resistance by Rajendran et al. [7].

The bath composition for electroless Ni-P deposition contains nickel chloride and sodium hypophosphite while the temperature was maintained at $85 \pm 1^{\circ} \mathrm{C}$. The solution $\mathrm{pH}$ was fixed between 9 and 10 by the addition of an adequate measure of ammonia solution.

The surface morphology of the EN coating was examined using a Jeol 6400 high-resolution scanning electron microscope (SEM). The phosphorus and nickel content of the EN deposits were analysed using Jeol 6400 SEM EDAX attachment $[7,8]$. In a few earlier investigations $[9,10]$ on zincate treatment for aluminium alloy surfaces, structure of 
the zinc particles and the effect due to roughening, brought by the substrate dissolving in the plating solution, were reported to affect adhesion of the electroless nickel-phosphorus (Ni-P) coating to the substrate [9-13].

Hajdu and Zabrocky [14] laudably designed surface preparation methods for EN deposition by using masking in preparation. Numerous components may need just partial coating using EN, and segment of the substrate must be guarded by masking. It is unfortunate that masking objects may discharge harmful metallic or organic contaminants into the bath.

Electroless Ni-P composite plating on $6061 \mathrm{Al}$ alloy has been investigated from acidic bath [15]. Aluminium alloy 6061 shows outstanding metallurgical and mechanical properties, corrosion resistance, and workability [16-18]. EN alloy deposits, particularly nickel-phosphorus alloys, are extensively used for corrosion protection of $\mathrm{Al}$ and steel [1518].

Ayoub [19] studied electroless Ni-P deposition on stainless steel and concluded that uniform, compact mixture of microstructures of amorphous and microcrystalline Ni-P coating (with 8.57 wt $\%$ P) can be effectively formed on the stainless steel substrate.

EN is well known for its hardness, abrasive wear, and corrosion resistance [7, 20-25]. Among the diverse surface engineering methods that are available for this purpose, EN coating is exceptionally accepted, especially in the electronic industry owing to its conductivity and numerous other engineering properties [15].

The effect of microstructure and plating parameters on the EN plating of AZ91D magnesium alloy were studied and reported by Ambat and Zhou [26]. In the report the early growth of electroless nickel on AZ91 and the variation of coating thickness as a function of time at constant temperature and $\mathrm{pH}$ were presented. The coating thickness was directly proportional to the plating time. It was inferred that both the precleaning steps and the concentration of bath components have the influence on EN coating. The consequence of these bath parameters on the EN deposition of $\mathrm{Mg}$ is not obtainable in the literature [26].

EN of different kinds are found to be very useful in many engineering applications for their wear and corrosion resistance characteristics. Das and Sahoo [27] studied the tribological qualities of electroless $\mathrm{Ni}-\mathrm{B}$ deposition and optimization of coating factors using Taguchi supported grey relational analysis. In another report, Gadhari and Sahoo [28] explored the influence of coating factors on the microhardness of electroless Ni-P- $\mathrm{Al}_{2} \mathrm{O}_{3}$ composite coating using Taguchi analysis. In the study, four parameters, concentrations of nickel sulphate, sodium hypophosphite, and $\mathrm{Al}_{2} \mathrm{O}_{3}$ particles and annealing temperature, were considered. The optimized condition is found to yield about $20.47 \%$ enhancement in hardness of the coating in contrast to the initial condition.

Mallory and Hajdu [29] investigated the effect of bath $\mathrm{pH}$ and reported that the $\mathrm{P} w \mathrm{t} \%$ reduces with increasing solution $\mathrm{pH}$ from 4.0 to 5.2. Singh et al. [30] carried out electroless plating on c-Si solar cell for diverse periods of time ranging from $30 \mathrm{~s}$ to longer durations (1-4 min). The main interest was to observe the effect of both immediate and the prolonged immersion on EN depositions. A pH 7.5 controlled alkaline bath was used for EN deposition while other experimental settings were kept unchanged for all the tests.

The metallurgical properties, wear, and corrosion behaviours of aluminium alloy used in the hydraulic brake master cylinder pistons immersed in brake fluid have been studied and reported [31-35]. In understudying and providing a remedy to this menace, Ajibola et al. [10] had reported the effect of hard surface grinding and activation on EN deposition on CAA substrates in sodium hypophosphite baths. The samples were polished with different grits $(60 \mu \mathrm{m}-$ $1200 \mu \mathrm{m})$ of emery paper prior to EN plating. The impact of polishing grits was studied on the adhesion, appearance, and quantity of EN deposition on substrates. The best yield in terms of adhesion and appearance was obtained from the activation in zincate and Palladium Chloride $\left(\mathrm{PdCl}_{2}\right)$ solutions among the six surfactants used [10]. The investigation on the effect of heat treatment for EN coating of Ni film on hollow glass beads was reported by Wang and Zhang [36]. The microstructures and component of EN film on glass beads surface were examined SEM/EDX. The report shows that the EN plating was uniform with the nickel element in the deposition being higher than $95.71 \mathrm{wt} \%$ fraction. Rajaguru et al. [37] reported the examination of EN deposition on PerFactory rapid prototype model made on PerFactory R05 material. The preactivation surface etching was found to have a noteworthy effect on surface and generates secure basement for finishing overlay.

It is well noted that commercially available electroless nickel baths contain important additives such as small amounts of lead, typically $0.5 \mathrm{ppm}$. Yet, there are many/different workable laboratory bath formulations that have been reported in the literature over the years. Each depends on the type and the nature of substrates (steels, cast iron, wrought $\mathrm{Al}$ alloy or cast $\mathrm{Al}$ alloy, $\mathrm{Mg}$ alloy, etc.). The present bath was fashioned after Winowlin Jappes [38, 39], as $\mathrm{Al}$ alloy is of our concerned substrate.

Most of the previous works in literature have attempted to report the EN plating of primary $\mathrm{Al}$ and how the plating parameters affect the properties. Some other reports have been devoted to A3000 and A7000 series of Al alloy based in hydrazine, sodium borohydride, aminoborane, and borohydride-reduced baths. These usually are examined at temperature between 85 and $90^{\circ} \mathrm{C}$ in $\mathrm{pH}$ of $4.0-5.2$ and $10-$ 12 controlled baths. However, not so much has been found reported on the use of cast Al6061 as a substrate for the EN plating in sodium-hyposphite bath. A6061 Al alloy seems to be one of the most readily available $\mathrm{Al}$ alloys in the metal markets in many developing countries. Thus the present study considered the effect of some other parameters such as the plating temperatures, solution $\mathrm{pH}$, and the immersion time on the protective quality of EN film on cast A6061Al alloy.

\section{Materials and Methods}

2.1. Chemical Analyses of Aluminium Alloy Substrates. The chemical compositions of aluminium alloy substrates were determined using Atomic Absorption Spectrometer (AAS) 
TABLE 1: Pretreatment and EN plating chemicals.

\begin{tabular}{|c|c|c|c|c|}
\hline Baths & Media & Volume $\left(\mathrm{cm}^{3}\right)$ & $\begin{array}{l}\text { Concentration } \\
(\mathrm{g} / \mathrm{L} \text { or } \mathrm{mL} / \mathrm{L})\end{array}$ & $\begin{array}{l}\text { Immersion } \\
\text { time (min) }\end{array}$ \\
\hline Rinsing & Water & 1000 & - & $0.5-1.0$ \\
\hline Emulsifying & $\begin{array}{l}\text { Emulsifier: kerosene } \\
\text { + detergent solution }\end{array}$ & 1000 & $\begin{array}{c}15 \mathrm{ml} \\
15 \mathrm{~g}\end{array}$ & $0.5-1.0$ \\
\hline $\begin{array}{l}\text { Alkaline } \\
\text { cleaning }\end{array}$ & Sodium hydroxide & 1000 & $0.4 \mathrm{~g}$ & $0.5-1.0$ \\
\hline Acid cleaning & Hydrochloric acid & 1000 & $5 \mathrm{~mL}$ & $0.5-1.0$ \\
\hline Surfactant & $\mathrm{PCl}_{2}$ & 1000 & $0.0-0.12 \mathrm{~g}$ & $0.5-0.75$ \\
\hline \multirow{5}{*}{ Plating } & Nickel chloride & \multirow{5}{*}{$3000-5000$} & $30 \mathrm{~g}^{*}$ & \multirow{5}{*}{$1-10$} \\
\hline & Sodium hypophosphite & & $40 \mathrm{~g}^{*}$ & \\
\hline & Sodium citrate & & $25 \mathrm{~g}^{*}$ & \\
\hline & Ammonium chloride & & $50 \mathrm{~g}^{*}$ & \\
\hline & $\mathrm{PCl}_{2}$ & & 0.02 & \\
\hline Post plating & $\begin{array}{l}\text { Antitarnish chemical: } \\
\text { potassium-dichromate solution }\end{array}$ & 1000 & $15 \mathrm{~g}$ & $2-3$ \\
\hline
\end{tabular}

${ }^{*}$ According to Winowlin Jappes [38].

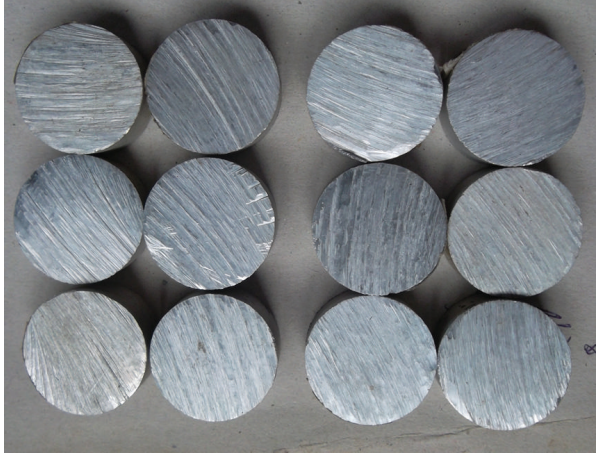

(a)

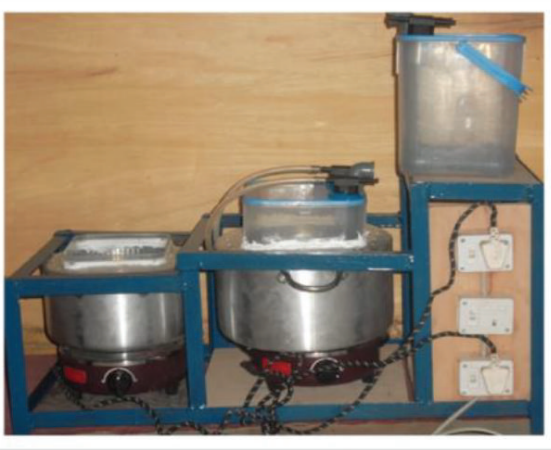

(b)

Figure 1: (a) Cast aluminium alloy specimen and (b) EN plating bath line [10].

TABLE 2: AAS chemical analysis of cast aluminium alloy (CAA).

\begin{tabular}{lccccccccc}
\hline Samples & $\mathrm{Al}$ & $\mathrm{Si}$ & $\mathrm{Mg}$ & $\mathrm{Fe}$ & $\mathrm{Mn}$ & $\mathrm{Cu}$ & $\mathrm{Zn}$ & $\mathrm{Cr}$ & $\mathrm{Ti}$ \\
\hline CAA & 98.44 & 0.32 & 0.29 & 0.16 & 0.001 & 0.01 & 0.001 & 0.001 & 0.001 \\
\hline
\end{tabular}

Thermo series 2000 Model (Table 2). The melting pot was charged with $2 \mathrm{~kg}$ scrap sourced from automobile brake master cylinder piston $[31,33]$ and melted at a temperature range of $750 \pm 50^{\circ} \mathrm{C}$ in an electric furnace. The molten metal was sand cast into rod of $300 \mathrm{~mm}$ length by $30 \mathrm{~mm}$ diameter. The rods were machined on the lathe and sliced to $15 \mathrm{~mm}$ thickness by $25 \mathrm{~mm}$ diameter (Figure 1). The specimens' surfaces were sequentially grinded and polished to smoothness/fine finishing, using $60 \mu \mathrm{m} \sim 1200 \mu \mathrm{m}$ grits of emery paper as reported by Ajibola et al. [10].

The list of the pretreatment and EN plating chemicals is shown in Table 1. The samples were cleaned and pretreated in series of chemicals (bases and acids) to prepare the surface for good quality adhesion. Each pretreatment stage is followed by water rinsing to remove the chemical that adheres to the surface. The surface activation is done in Palladium Chloride $\left(\mathrm{PdCl}_{2}\right)$ solution at $85^{\circ} \mathrm{C}[10]$ before they are finally immersed in the electroless nickel bath (Figure 1). Three parameters were varied: plating time, $\mathrm{pH}$, and temperature. The time (1$10)$ is in minutes, temperatures $(70,75,80,85,90$, and 95) are in ${ }^{\circ} \mathrm{C}$, and the solution $\mathrm{pH}$ is of 5.0 to 6.5 (acid bath, $\mathrm{NaOH}$ regulated) and of 7.0 to 11.5 (alkaline bath, $\mathrm{NH}_{4} \mathrm{OH}$ controlled). The surface condition of the substrate $(1200 \mu \mathrm{m}$ grit polishing paper) and $\mathrm{PdCl}_{2}$ (activation) parameters were kept constant.

The EN deposited per unit area was calculated using

$$
\text { EN deposited per unit area }=\frac{\Delta W}{A_{T}},
$$

where

$$
\Delta W=W_{f}-W_{i},
$$

where $\Delta W$ is weight of EN deposition, $A_{T}$ is total surface area of substrate, $t$ is plating time, and $W_{i}$ and $W_{f}$ are weights of the sample before and after immersion, respectively. 
TABLE 3: Effect of plating time variation on electroless nickel deposition.

\begin{tabular}{lcc}
\hline Plating time $(\mathrm{min})$ & Deposition $\left(\mathrm{g} / \mathrm{mm}^{2}\right)$ & Appearances (quality) \\
\hline 1 & 0.000177 & Uniform deposits \\
2 & 0.000236 & Uniform deposits \\
3 & 0.000256 & Uniform deposits \\
4 & 0.000276 & Uniform deposits \\
5 & 0.000284 & Tendency to peel \\
6 & 0.000316 & Uniform deposits \\
7 & 0.000396 & Flaky, metallic \\
8 & 0.000415 & Flaky \\
9 & 0.000428 & Metallic \\
10 & 0.000434 & Metallic \\
\hline
\end{tabular}

TABLE 4: EDX spectrum data for 2 min EN plating on cast $\mathrm{Al}$ alloy.

\begin{tabular}{lccccccccc}
\hline Element & $\mathrm{C}$ & $\mathrm{O}$ & $\mathrm{Na}$ & $\mathrm{Ni}$ & $\mathrm{P}$ & $\mathrm{Al}$ & $\mathrm{Si}$ & $\mathrm{Cr}$ & Total \\
\hline $\begin{array}{l}\text { Weight \% } \\
11.65\end{array}$ & 23.28 & 3.28 & 17.86 & 0.82 & 39.57 & 7.66 & -4.10 & 100 \\
$\begin{array}{l}\text { Atomic } \\
\%\end{array}$ & 21.27 & 31.92 & 3.13 & 6.67 & 0.58 & 32.18 & 5.98 & -1.73 & \\
\hline
\end{tabular}

After the plating process, coated surface is washed in antitarnish chemical and water rinsed to prevent unwanted stains and dried in the oven; after that, the amount of EN deposition per area and the microstructure were examined.

The substrate samples were characterised by AAS (Thermo series 2000 model). The microstructures were examined to compare the similarities and differences in the grain sizes and the structures under the microscope (Nikon-Eclipse M600 model). The surface morphology and characterisation of the coating were studied through the scanning electron microscope (Jeol JSM-7600F Microscope) with the EDX facilities attachment. Such varying parameters under which the SEM/EDX studies were performed are $\mathrm{kV}$ value $(1.0 \mathrm{kV}, 10.0 \mathrm{kV})$; magnifications $(\times 100, \times 500, \times 1000$, $\times 2000, \times 10000, \times 30000)$; resolutions (LM, GB_HIGH); image/spectrum target size $(100 \mathrm{~nm}, 1 \mu \mathrm{m}, 10 \mu \mathrm{m}$, and $100 \mu \mathrm{m})$; and WD $(7.9,8.0,8.3$, and $10.1 \mathrm{~mm})$. These are reportedly shown on each of the micrographs.

\section{Results and Discussion}

Table 2 shows the chemical compositions of CAA sample used for the experiment as obtained by AAS. The average hardness (BHN) value was determined as means of identifying its behaviour under friction with respect to the composition and microstructure. With these characterisations, some reasons for the plating, wear, and corrosion resistance behaviours could be understood.

3.1. Effect of Plating Time on Electroless Nickel Deposition. Effects of plating time variation on the amount and physical appearances of the EN deposition on CAA are presented in Tables $3-5$ and Figures 2 and 3.

The effects of plating time on the amount of EN deposition on CAA are presented in SEM imagery in Figure 3.
TABLE 5: EDX spectrum data for $10 \mathrm{~min} \mathrm{EN}$ plating on cast $\mathrm{Al}$ alloy.

\begin{tabular}{lccccccccc}
\hline Element & $\mathrm{C}$ & $\mathrm{O}$ & $\mathrm{Na}$ & $\mathrm{Ni}$ & $\mathrm{P}$ & $\mathrm{Al}$ & $\mathrm{Si}$ & $\mathrm{Cr}$ & Total \\
\hline $\begin{array}{l}\text { Weight } \\
\%\end{array}$ & 9.50 & 9.31 & 1.47 & 55.79 & 2.28 & 22.08 & 0.44 & -0.87 & 100 \\
$\begin{array}{l}\text { Atomic } \\
\%\end{array}$ & 24.13 & 17.75 & 1.94 & 28.99 & 2.25 & 24.96 & 0.48 & -0.51 & \\
\hline
\end{tabular}

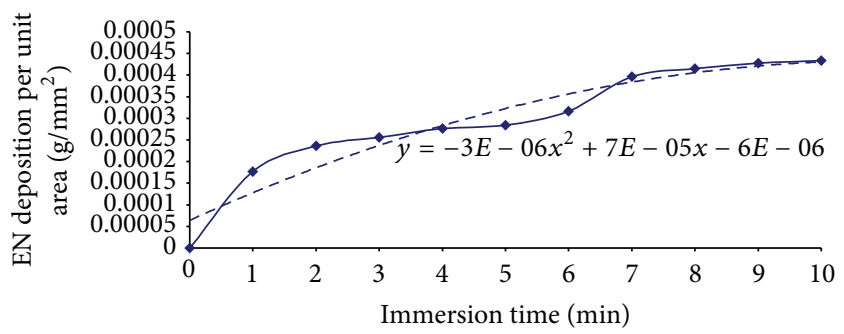

$$
\begin{aligned}
& \longrightarrow \text { EN on CAA } \\
& \ldots-- \text { Poly. (EN on CAA) }
\end{aligned}
$$

FIgURE 2: Variation of plating time on EN deposition per unit area on cast $\mathrm{Al}$ alloy (CAA) substrates.

Electroless nickel was deposited on CAA substrates with time varying from 1 to 10 minutes in sodium hypophosphite reduced bath. It was observed that the quantity of electroless nickel deposition per unit area is dependent on the time, whereas the adhesion and brightness are not controlled by the plating immersion time.

Figure 2 shows the effect of the variation of plating time (from 1 to 10 minutes) on EN deposition per unit area on CAA substrates. The EN deposition per unit area increases with the increasing plating time at very close and similar trends of CAA substrates. Small amounts of CAA deposition $\left(0.000177\right.$ to $\left.0.000434 \mathrm{~g} / \mathrm{mm}^{2}\right)$ were obtained per unit area of the CAA substrate. The trend of the EN deposition per unit area with respect to increasing plating time was studied using the experimental data generated from the experiment. The curve fit parameters model is of polynomial power 2 relating the EN deposition per unit area to time (minutes) presented as

$$
M_{n 1}=-0.000003 t^{2}+0.00007 t-0.000006,
$$

where $t$ is plating time, $t>0$ (minute), and $M_{n 1}$ is the EN deposition per unit area with respect to plating time on CAA in sodium hypophosphite reduced bath. About $0.000434 \mathrm{~g}$ maximum EN deposition per $\mathrm{mm}^{2}$ area of the CAA substrate was obtained in 10 minutes. The results show that the EN deposition rate increased from 0.000177 to $0.0000434 \mathrm{~g} / \mathrm{mm}^{2} / \mathrm{min}$ for the CAA within the increasing 1 to 10 minutes plating time frame.

The microscopic outlooks of the EN films are revealed in the SEM electron images in Figure 3. The SEM image in Figure 3(a) shows the homogeneous layer of nickelphosphorous coating similar to the results of the morphology study by Rajaguru et al. [37]. The EDX spectrum data show the chemical compositions of the characterisations of the EN deposition in Tables 4 and 5. The EDX data inferred that the 


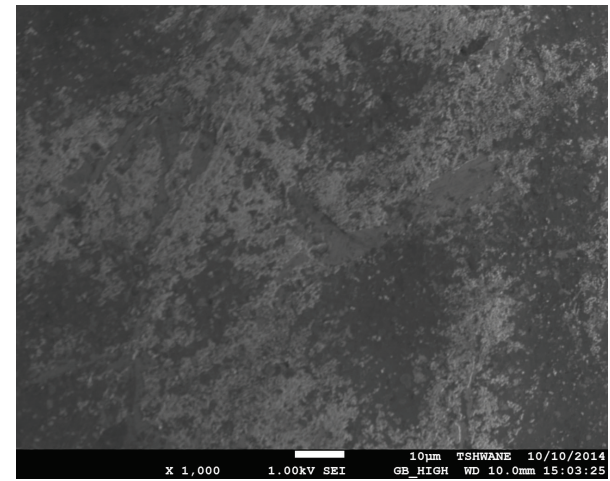

(a)

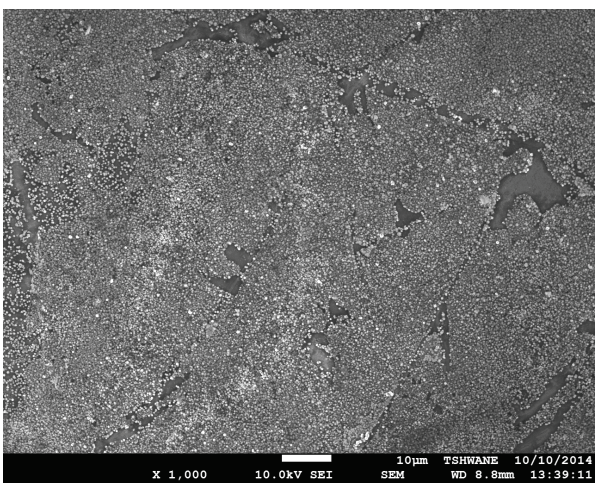

(c)

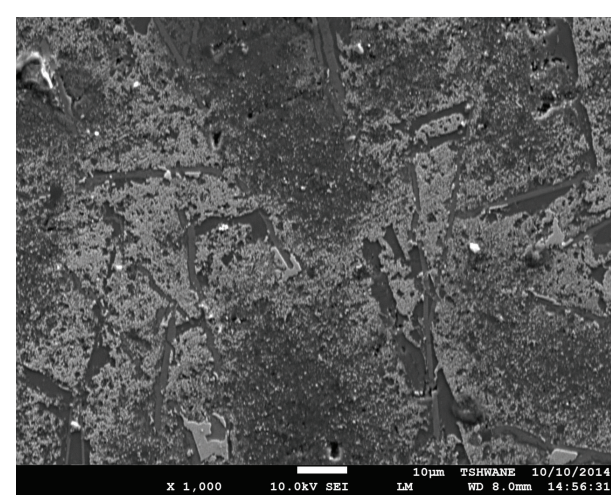

(b)

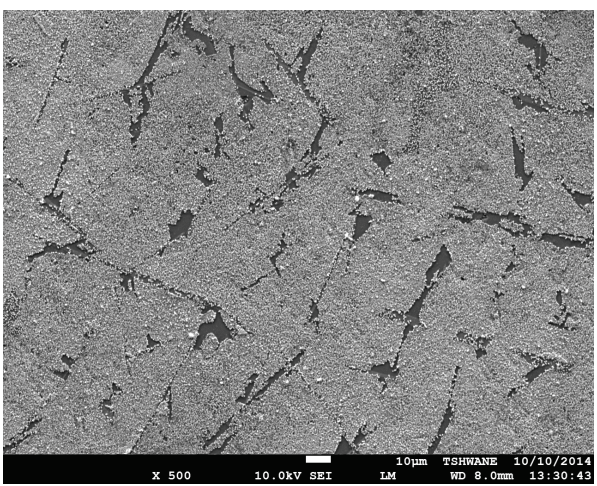

(d)

FIGURE 3: SEM images showing EN films on CAA surfaces after (a) 2, (b) 4, (c) 8, and (d) 10 minutes of immersion.

TABLE 6: Effect of plating temperature variation on electroless nickel deposition.

\begin{tabular}{lcc}
\hline Temperature $\left({ }^{\circ} \mathrm{C}\right)$ & Deposition $\left(\mathrm{g} / \mathrm{mm}^{2}\right)$ & Appearances (quality) \\
\hline 70 & 0.000179 & Nonmetallic, very poor \\
75 & 0.000231 & Nonmetallic, peeling \\
80 & 0.000121 & Metallic, peeling \\
85 & 0.000138 & Metallic, uniform \\
90 & 0.000244 & Metallic, flaky \\
95 & 0.000236 & Metallic, peeling \\
\hline
\end{tabular}

EN deposition increased with the immersion. This correlates with what is presented in the weight gain measurement in Table 3 and Figure 2.

3.2. Effect of Plating Temperature Variation on Electroless Nickel Deposition. Effect of plating temperature variation on the quantity and appearances of the EN deposition on CAA are shown in Tables 6-9 and Figures 4 and 5.

Issues arise about the efficiency of washing off the plating bath residue on samples when, for example, the ten-minute plating EDX data presented in Table 5 shows the presence of $1.47 \mathrm{wt} \%$ sodium, Na. Though, the situation may partially arise from the washing off plating bath residue on EDX samples. The presence of substantial amount of wt\% sodium, $\mathrm{Na}$, detected and reported in the EDX data (Tables $4-8$ ), is
TABLE 7: EDX spectrum data for 10 min EN plating on cast $\mathrm{Al}$ alloy at (a) $80^{\circ} \mathrm{C}$

\begin{tabular}{lcccccccccc}
\hline Element & $\mathrm{C}$ & $\mathrm{O}$ & $\mathrm{Na}$ & $\mathrm{Al}$ & $\mathrm{Si}$ & $\mathrm{P}$ & $\mathrm{Cl}$ & $\mathrm{Ca}$ & $\mathrm{Ni}$ & Total \\
\hline $\begin{array}{l}\text { Weight \% } \\
13.19\end{array}$ & 13.44 & 1.15 & 0.26 & 0.33 & 4.43 & 0.55 & 0.33 & 66.31 & 100 \\
$\begin{array}{l}\text { Atomic } \\
\%\end{array}$ & 33.22 & 25.41 & 1.51 & 0.30 & 0.36 & 4.33 & 0.47 & 0.25 & 34.16 & \\
\hline
\end{tabular}

TABLE 8: EDX spectrum data for 10 min EN plating on cast $\mathrm{Al}$ alloy at (b) $85^{\circ} \mathrm{C}$.

\begin{tabular}{lccccccc}
\hline Element & $\mathrm{C}$ & $\mathrm{O}$ & $\mathrm{Al}$ & $\mathrm{Na}$ & $\mathrm{P}$ & $\mathrm{Ni}$ & Total \\
\hline Weight \% & 7.60 & 7.86 & - & 1.06 & 3.98 & 79.48 & 100 \\
Atomic \% & 23.90 & 18.51 & - & 1.74 & 4.84 & 51.01 & \\
\hline
\end{tabular}

TABLE 9: EDX spectrum data for EN plating on cast Al alloy at (c) $90^{\circ} \mathrm{C}$.

\begin{tabular}{lccccccccc}
\hline Element & $\mathrm{C}$ & $\mathrm{O}$ & $\mathrm{Al}$ & $\mathrm{Si}$ & $\mathrm{P}$ & $\mathrm{S}$ & $\mathrm{Fe}$ & $\mathrm{Ni}$ & Total \\
\hline $\begin{array}{l}\text { Weight } \\
\%\end{array}$ & 9.75 & 12.82 & 51.23 & 13.53 & 0.60 & 0.27 & 2.39 & 9.40 & 100 \\
$\begin{array}{l}\text { Atomic } \\
\%\end{array}$ & 19.22 & 18.97 & 44.94 & 11.41 & 0.46 & 0.20 & 1.01 & 3.79 & \\
\hline
\end{tabular}

most likely due to the imperfections such as trapped Na-bath solution in the pores and at the interface between the EN deposit and the $\mathrm{Al}$ alloy substrate due to poor adhesion. 


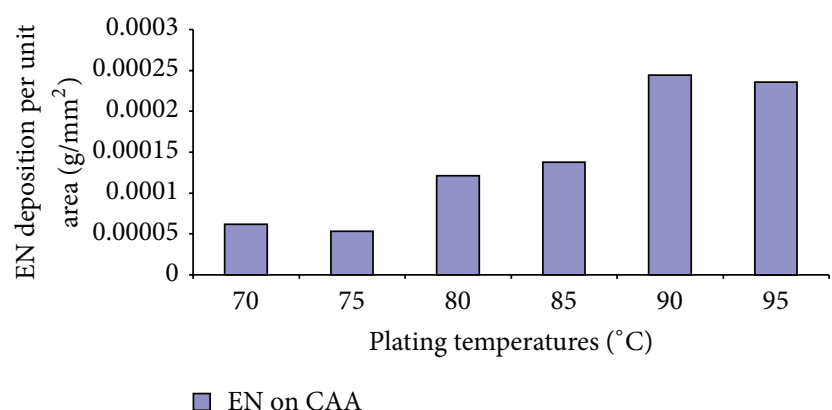

FIgURE 4: Variation of plating temperature on electroless nickel deposition per unit area on cast $\mathrm{Al}$ alloy (CAA) substrates.

The effects of plating temperature variation on EN deposition on CAA in acidic sodium hypophosphite reduced bath are presented in Figures 4 and 5. The qualities (morphologies such as the appearance, roughness, porosity, and film continuity) of the EN deposition on the $1200 \mu \mathrm{m}$ grit polished CAA substrates at $80^{\circ} \mathrm{C}, 85^{\circ} \mathrm{C}$, and $90^{\circ} \mathrm{C}$, respectively, at microscopic level are compared in the SEM images in Figure 5. It was shown that the amount of $\mathrm{EN}$ deposition increased as the bath temperature increased from $80^{\circ} \mathrm{C}$ to $90^{\circ} \mathrm{C}$. From the result, the film properties (adhesion and brightness) are dependent on the plating temperature and the best of the adhesion of EN films on CAA were in most cases obtained at temperatures higher than $80^{\circ} \mathrm{C}$. The amount of EN deposition on the CAA substrates is temperature controlled as the bath temperature increased from 80 to $90^{\circ} \mathrm{C}$. The highest EN nickel deposition per unit area was obtained at $90^{\circ} \mathrm{C}$. There is little difference in the EN film per unit area on CAA as temperature increased from 80 to $85^{\circ} \mathrm{C}$, above which there was much increase in the EN film per unit area obtained on the CAA substrate, even though, this did not bring significant improvement in the qualities of the EN deposition.

The curve fit parameters model developed is of polynomial function to power 2 relating the EN deposited to the bath temperature $\left({ }^{\circ} \mathrm{C}\right)$ as in

$$
M_{n 1}=4 E-05 T^{2}-0.0001 T+0.0002
$$

where $80 \leq T \geq 90, T$ is plating bath temperature ${ }^{\circ} \mathrm{C}$, and $M_{n 1}$ is the EN deposition per unit area. The EN plating requires a high amount of energy for the autocatalytic reaction to be effective. The kinetics of the reaction is temperature controlled. EN is deposited at the rates of 1.79E-05-2.31E-05 range $\left(\mathrm{g} / \mathrm{mm}^{2} / \mathrm{min}\right)$ on CAA at the temperature range of 80 to $85^{\circ} \mathrm{C}$, respectively.

3.3. Effect of Solution pH on the Electroless Nickel Film. Effects of solution $\mathrm{pH}$ on the amount and qualities of the EN deposition on CAA substrates are in Tables 10-16 and Figures 6-8.

The function played by intermetallic particles in surface preparation of $\mathrm{Al}$ alloys for $\mathrm{EN}$ plating using double zincating method of surface activation is in a few words explained in the US Patent 5,405,646. For cleaned substrates activated in $\mathrm{PdCl}_{2}$ and EN plated surfaces, it will be also admitted that the heterogeneous electrochemical characteristic of the alloy $(\mathrm{A} 6061 \mathrm{Al})$ surface plays a role in Palladium $(\mathrm{Pd})$ activation as applied to the present study.

The amphoteric nature of aluminium makes it react with both acids and alkaline and bases. The $\mathrm{pH}$ of the bath was maintained by adding required quantity of liquor ammonia. A number of systems have been imagined and projected for the chemical reactions that transpire in hypophosphite reduced EN plating solutions. The most comprehensively recognized mechanism and sequence as given by $\mathrm{R}$. C. Agarwala and V. Agarwala [40] are in the following:

$$
\begin{aligned}
& \left(\mathrm{H}_{2} \mathrm{PO}_{2}\right)^{-}+\left(\mathrm{H}_{2} \mathrm{O}\right) \text { [Heat, Catalyst] } \\
& =\mathrm{H}^{+}+\left(\mathrm{HPO}_{3}\right)^{-2}+2 \mathrm{H}_{\mathrm{abs}} \\
& \mathrm{Ni}_{2}+2 \mathrm{H}_{\mathrm{abs}}=\mathrm{Ni}+2 \mathrm{H}^{+} \\
& \left(\mathrm{H}_{2} \mathrm{PO}_{2}\right)^{-}+\mathrm{H}_{\mathrm{abs}}=\mathrm{H}_{2} \mathrm{O}+\mathrm{OH}^{-}+\mathrm{P} \\
& \left(\mathrm{H}_{2} \mathrm{PO}_{2}\right)^{-}+\mathrm{H}_{2} \mathrm{O}=\mathrm{H}^{+}+\left(\mathrm{HPO}_{3}\right)^{2-}+\mathrm{H}_{2}
\end{aligned}
$$

With the sufficient amount of energy and catalysed surface, hypophosphite ions are oxidized to orthophosphite. Hydrogen gas is evolved in the process which is detrimental to the EN deposit film morphology and affects the porosity. Hence, stirring conditions are necessary to remove evolved hydrogen bubbles.

Effect of variation of solution $\mathrm{pH}$ on the quantity and qualities of EN deposition on $1200 \mu \mathrm{m}$ grit polished CAA substrates at various $\mathrm{pH}$ and temperatures in both the acid and alkaline reduced baths are presented in Figures 6 and 7. In the acid reduced bath, the amount and quality of EN deposition were significantly affected by the level of solution $\mathrm{pH}$.

The immersed substrate is very much aggressive in the plating baths. This affects the surface morphology of the CAA. EN coatings follow the surface profile of the substrate on which it is deposited. Hence, the roughness of the substrate has a profound impact on the tribological properties of the coating while the roughness of the substrate affected the film composition [3, 4]. Hence, there is significant need to zincate the CAA substrate prior to the immersion into the plating baths. The intersection zinc film between the substrate and the EN solution reduces the early alteration of the CAA substrate prior to EN deposition. The film properties such as adhesion and brightness are dependent on the $\mathrm{pH}$ of the plating solution. This might account for why superior adhesion was previously reported from the zincating experiment [10].

EN preferentially deposited on the stainless steel vat at $85^{\circ} \mathrm{C}$ and $\mathrm{pH}=5.1$ without $\mathrm{pH}$ regulator (Figure 7). The deposition is full bright metallic and of very high level of adhesion and continuity. Other SEM images in Figure 7 show EN deposition on $1200 \mu \mathrm{m}$ grit polished CAA substrates at $80^{\circ} \mathrm{C}$ in $\mathrm{pH}=5.2$ using $\mathrm{NaOH}$ regulated bath. The plating comes with fairly bright deposit and good adhesion to the CAA substrate. In the $\mathrm{pH}$ (5.3) acid reduced baths, the deposition consists of both dull nonmetallic and bright metallic EN films on the CAA. The adhesion is poor and hence, the 


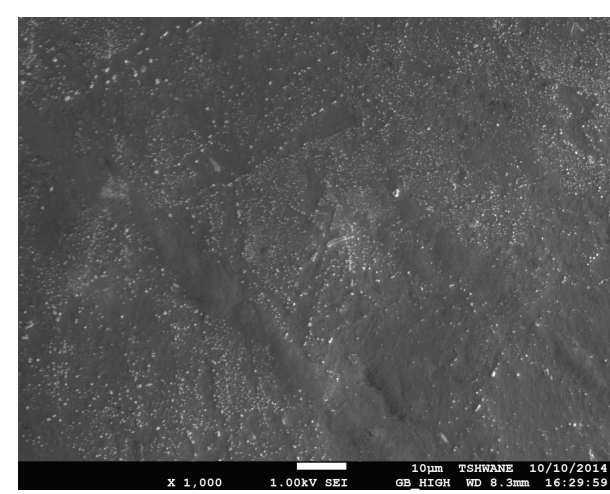

(a)

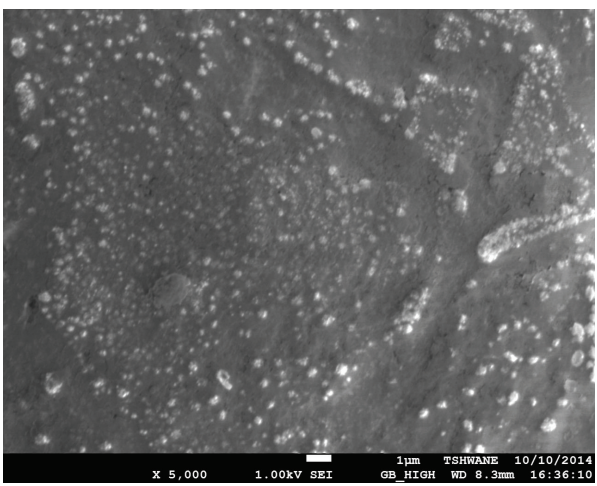

(c)

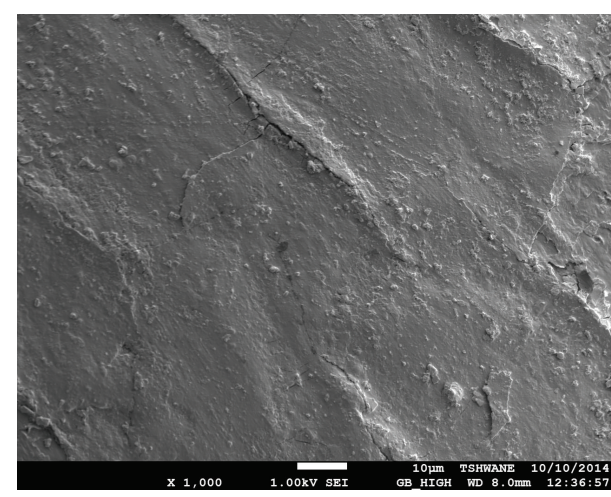

(b)

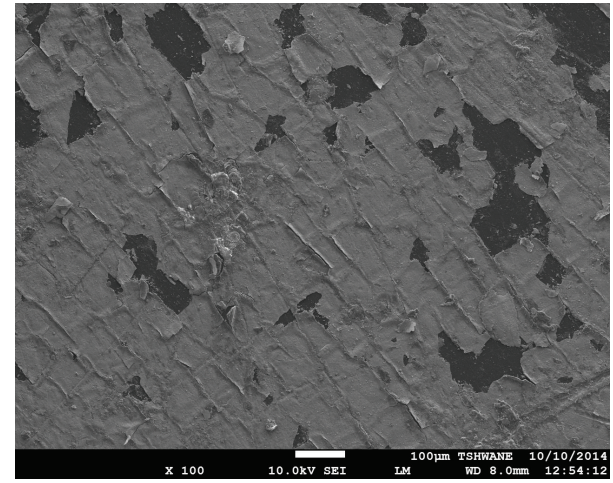

(d)

Figure 5: Microphotographs showing EN deposition on $1200 \mu \mathrm{m}$ grit polished cast $\mathrm{Al}$ alloy (CAA) substrates at (a) $80^{\circ} \mathrm{C}$, (b) $85^{\circ} \mathrm{C}$, and (c) $90^{\circ} \mathrm{C}$ plating temperatures.

TABLE 10: Effect of solution $\mathrm{pH}$ variation on electroless nickel deposition.

\begin{tabular}{|c|c|c|c|c|c|}
\hline \multicolumn{3}{|c|}{ Acid bath } & \multicolumn{3}{|c|}{ Alkaline bath } \\
\hline $\mathrm{pH}$ & Deposition $\left(\mathrm{g} / \mathrm{mm}^{2}\right)$ & Appearances & $\mathrm{pH}$ & Deposition $\left(\mathrm{g} / \mathrm{mm}^{2}\right)$ & Appearances (quality) \\
\hline 5.0 & 0.000275 & Metallic & 9.0 & 0.000252 & Flaky, metallic \\
\hline 5.1 & 0.000273 & Metallic & 9.5 & 0.000286 & Metallic \\
\hline 5.2 & 0.000312 & Metallic & 10.0 & 0.000302 & Metallic \\
\hline 5.3 & 0.000399 & Nonmetallic, & 10.1 & 0.000223 & Poor, peeling \\
\hline 5.4 & 0.000421 & Poor & 10.2 & 0.000221 & Poor \\
\hline 5.5 & 0.000443 & Poor & 10.3 & 0.000257 & Flaky \\
\hline 6.0 & 0.000303 & Very poor & 10.4 & 0.000253 & Metallic, peeling \\
\hline 6.5 & 0.000308 & Very poor & 10.5 & 0.000352 & Metallic, bright \\
\hline 7.0 & 0.000334 & Very poor & 10.6 & 0.000229 & Flaky, metallic \\
\hline 7.5 & 0.000361 & Very poor & 10.7 & 0.000376 & Flaky, metallic \\
\hline 8.0 & 0.000325 & Very poor ${ }^{c}$ & 11.0 & 0.000322 & Metallic, flaky \\
\hline 8.5 & 0.000354 & Poor & 11.5 & 0.000343 & Metallic, uniform \\
\hline
\end{tabular}

deposit is pilling. At $\mathrm{pH}=5.4 \mathrm{NaOH}$ regulated $\mathrm{EN}$ bath, though the EN film is fairly bright, it is not continuous and having poor adhesion on the CAA substrate. Better adhesion of EN film on CAA was obtained at $\mathrm{pH}$ operated between 5.1 and 5.2, while EN deposited on the plastic substrates (lining) at $\mathrm{pH}$ between 5.3 and 5.4 for an acid reduced EN bath run at $85^{\circ} \mathrm{C}$. Different levels of poor qualities of EN film were deposited at solution $\mathrm{pH}$ 5.5-8.5 range operated at diverse temperatures.

Figure 8 shows the quality of EN film on $1200 \mu \mathrm{m}$ grit polished CAA in solution $\mathrm{pH}$ of 9.5 , and $\mathrm{NH}_{4} \mathrm{OH}$ regulated bath. The EN deposition forms with a little quantity of fairly poor adhered dull metallic film whereas the EN plating at $\mathrm{pH}=$ 10.5 and 11.0 in $\mathrm{NH}_{4} \mathrm{OH}$ regulated bath at $85^{\circ} \mathrm{C}$ produced 


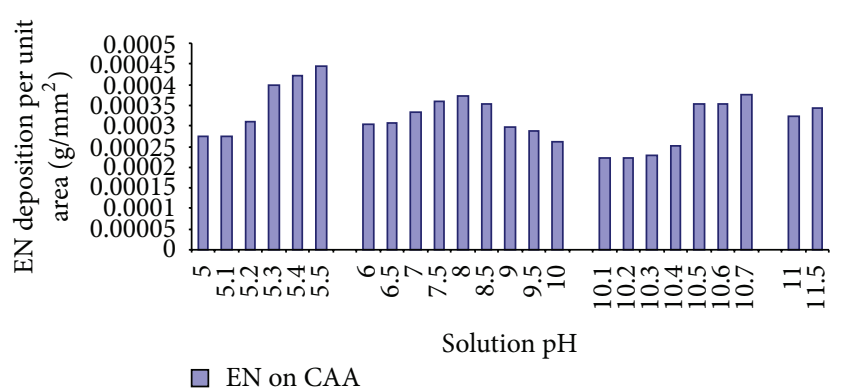

FIgURE 6: Variation of $\mathrm{pH}$ on electroless nickel deposition per unit area on as-received $\mathrm{Al}$ alloy (AAA) and cast $\mathrm{Al}$ alloy (CAA).

TABLE 11: EDX spectrum data for Ni-P plated CAA at $\mathrm{pH}=5.2$ $\mathrm{NaOH}$ regulated at $80^{\circ} \mathrm{C}$.

\begin{tabular}{lccccccccc}
\hline Element & $\mathrm{C}$ & $\mathrm{O}$ & $\mathrm{Na}$ & $\mathrm{Ni}$ & $\mathrm{P}$ & $\mathrm{Al}$ & $\mathrm{Si}$ & $\mathrm{Cr}$ & Total \\
\hline $\begin{array}{l}\text { Weight } \\
\%\end{array}$ & 8.16 & 7.79 & 1.81 & 67.51 & 1.96 & 9.63 & 4.26 & -1.13 & 100 \\
$\begin{array}{l}\text { Atomic } \\
\%\end{array}$ & 23.08 & 16.53 & 2.68 & 39.04 & 2.15 & 12.11 & 5.15 & -0.74 & \\
\hline
\end{tabular}

TABLE 12: EDX spectrum data for Ni-P plated CAA at $\mathrm{pH}=5.3$ $\mathrm{NaOH}$ regulated at $80^{\circ} \mathrm{C}$.

\begin{tabular}{lccccccccc}
\hline Element & $\mathrm{C}$ & $\mathrm{O}$ & $\mathrm{Na}$ & $\mathrm{Ni}$ & $\mathrm{P}$ & $\mathrm{Al}$ & $\mathrm{Si}$ & $\mathrm{Cr}$ & Total \\
\hline $\begin{array}{l}\text { Weight } \\
\%\end{array}$ & 8.73 & 7.36 & 1.65 & 70.94 & 2.31 & 11.41 & 0.31 & -2.71 & 100 \\
$\begin{array}{l}\text { Atomic } \\
\%\end{array}$ & 24.87 & 15.73 & 2.45 & 41.33 & 2.55 & 14.46 & 0.38 & -1.76 & \\
\hline
\end{tabular}

TABLE 13: EDX spectrum data for Ni-P plated CAA at $\mathrm{pH}=5.4$ $\mathrm{NaOH}$ regulated at $80^{\circ} \mathrm{C}$.

\begin{tabular}{lccccccccc}
\hline Element & $\mathrm{C}$ & $\mathrm{O}$ & $\mathrm{Na}$ & $\mathrm{Ni}$ & $\mathrm{P}$ & $\mathrm{Al}$ & $\mathrm{Si}$ & $\mathrm{Cl}$ & Total \\
\hline $\begin{array}{l}\text { Weight } \\
\%\end{array}$ & 6.38 & 9.05 & 0.47 & 61.40 & 1.37 & 18.33 & 2.62 & 0.35 & 100 \\
$\begin{array}{l}\text { Atomic } \\
\%\end{array}$ & 17.77 & 18.92 & 0.69 & 34.97 & 1.48 & 22.72 & 3.12 & 0.33 & \\
\hline
\end{tabular}

metallic $\mathrm{Ni}$ with fairly good adhesion as compared with what was obtained on the stainless steel substrate. At higher $\mathrm{pH}$ (11.5), there is preferential EN deposition on the plastic substrates (lining and stirrer) in the $\mathrm{NH}_{4} \mathrm{OH}$ regulated bath at $85^{\circ} \mathrm{C}$. In the alkaline reduced $\mathrm{EN}$ bath, the amount and quality of EN deposition were significantly influenced by the solution $\mathrm{pH}$ level. The film properties such as adhesion and brightness are dependent on the $\mathrm{pH}$ of the plating solution. Operating the electroless nickel bath at $\mathrm{pH}=9.0$ produces metal flakes of EN on the CAA coins substrate. The best of adhesion of EN film on CAA was obtained at $\mathrm{pH}$ operated within 10.5, 11.0, and 11.5, while there is full bright metallic and strongly adhered electroless nickel deposition on the plastic substrates (lining) at $\mathrm{pH}$ of $11.5 \mathrm{in}$ an alkaline reduced bath run at $85^{\circ} \mathrm{C}$. The general observation shows that solution $\mathrm{pH}$
TABLE 14: EDX spectrum data for Ni-P plated CAA at $\mathrm{pH}=10.5$ $\mathrm{NH}_{4} \mathrm{OH}$ regulated at $85^{\circ} \mathrm{C}$.

\begin{tabular}{lcccccccccc}
\hline Element & $\mathrm{C}$ & $\mathrm{O}$ & $\mathrm{Na}$ & $\mathrm{Al}$ & $\mathrm{Si}$ & $\mathrm{P}$ & $\mathrm{Fe}$ & $\mathrm{Ni}$ & $\mathrm{Pd}$ & Total \\
\hline $\begin{array}{l}\text { Weight } \\
\%\end{array}$ & 7.33 & 15.84 & 0.48 & 46.29 & 9.27 & 0.73 & 6.74 & 12.42 & 0.91 & 100 \\
$\begin{array}{l}\text { Atomic } \\
\%\end{array}$ & 15.13 & 24.56 & 0.51 & 42.57 & 8.19 & 0.58 & 2.99 & 5.25 & 0.21 & \\
\hline
\end{tabular}

TABLE 15: EDX spectrum data for Ni-P plated CAA at $\mathrm{pH}=11.0$ $\mathrm{NH}_{4} \mathrm{OH}$ regulated at $85^{\circ} \mathrm{C}$.

\begin{tabular}{lcccccccccc}
\hline Element & $\mathrm{C}$ & $\mathrm{O}$ & $\mathrm{Al}$ & $\mathrm{Si}$ & $\mathrm{P}$ & $\mathrm{S}$ & $\mathrm{Cl}$ & $\mathrm{Ni}$ & $\mathrm{Zn}$ & Total \\
\hline $\begin{array}{l}\text { Weight } \\
\%\end{array}$ & 10.57 & 13.63 & 51.98 & 13.57 & 0.70 & 0.31 & 0.27 & 7.98 & 0.98 & 100 \\
$\begin{array}{l}\text { Atomic } \\
\%\end{array}$ & 20.31 & 19.66 & 44.47 & 11.15 & 0.52 & 0.22 & 0.18 & 3.14 & 0.35 & \\
\hline
\end{tabular}

has a significant influence on the appearance and adhesion of EN deposit on CAA substrate.

In Figure 6, the amount of EN deposition per unit area on CAA substrates in acid and alkaline reduced baths is reported. The $\mathrm{pH}$ of the bath was varied from 5.1 to 5.5 for the acid bath. The amount of EN deposition on the CAA varies with the increasing solution $\mathrm{pH}$. A range of $0.000273-$ $0.000443 \mathrm{~g} / \mathrm{mm}^{2} \mathrm{EN}$ film was obtained. The results show that at lower values of solution $\mathrm{pH}(5.0-5.2)$, there is less EN deposition per unit area on the CAA substrate. Subsequently, at $\mathrm{pH}$ of 5.3 and above, there is greater increase in the electroless nickel deposition per unit area on CAA substrate in the acid bath. The trend of the EN deposited per unit area with respect to increasing plating solution $\mathrm{pH}$ was studied, using the experimental data generated from the experiment. The developed model is given as in

$$
M_{n 1}=0.000000009 x^{2}+0.00003 x+0.0002,
$$

where $x$ is solution $\mathrm{pH}, 5.0 \leq x \geq 5.5$, and $M_{n 1}$ is the EN deposition per unit area on CAA in acid sodium hypophosphite reduced baths.

In Figure 6, there is greater EN deposition per unit area on the CAA substrate in solutions of $\mathrm{pH}$ (9 to 11) lower than 11.5 in the alkaline bath. There was an increase in EN deposition per unit area from increasing $\mathrm{pH}$ from 5.0 to 5.5, above which the EN deposition per unit area reduced between 6.0 and 10.4. There was high EN deposition per unit area from increasing $\mathrm{pH}$ from 10.5 to 11.5 as compared with what was obtained at $\mathrm{pH}$ range of 10.1 to 10.4 , and $\mathrm{NH}_{4} \mathrm{OH}$ regulated solution. The quantity of EN deposition per unit area could be considered to increase with increasing solution $\mathrm{pH}$ for CAA substrates at $\mathrm{pH} 10.5-11.5$ range regulated by $\mathrm{NH}_{4} \mathrm{OH}$ solution. The model equation derived using MS Excel is of polynomial equation to power 2 relating the amount of EN deposited on CAA to the plating solution $\mathrm{pH}$ given as in

$$
M_{n 3}=-0.000004 x^{2}+0.00005 x+0.0002,
$$


TABLE 16: EDX spectrum data for $\mathrm{Ni}-\mathrm{P}$ plated CAA at $\mathrm{pH}=11.5 \mathrm{NH}_{4} \mathrm{OH}$ regulated at $85^{\circ} \mathrm{C}$.

\begin{tabular}{lcccccccc}
\hline Element & $\mathrm{C}$ & $\mathrm{O}$ & $\mathrm{Na}$ & $\mathrm{Al}$ & $\mathrm{Si}$ & $\mathrm{P}$ & $\mathrm{Ni}$ & Total \\
\hline Weight \% & 6.00 & 5.09 & 0.35 & 6.67 & 9.60 & - & 72.30 & 100 \\
Atomic \% & 18.82 & 11.99 & 0.57 & 9.32 & 12.89 & - & 46.42 \\
\hline
\end{tabular}

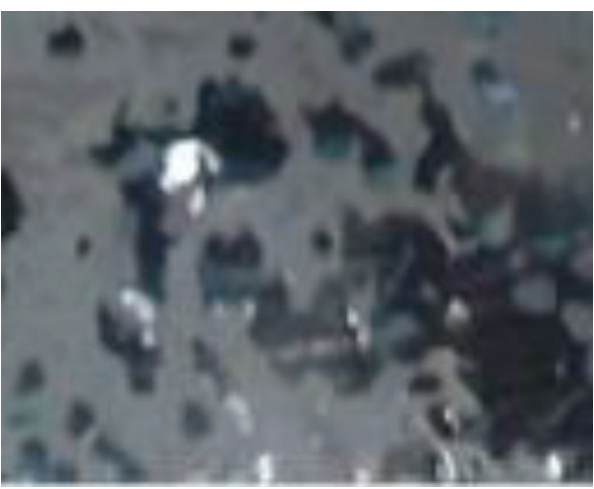

(a)

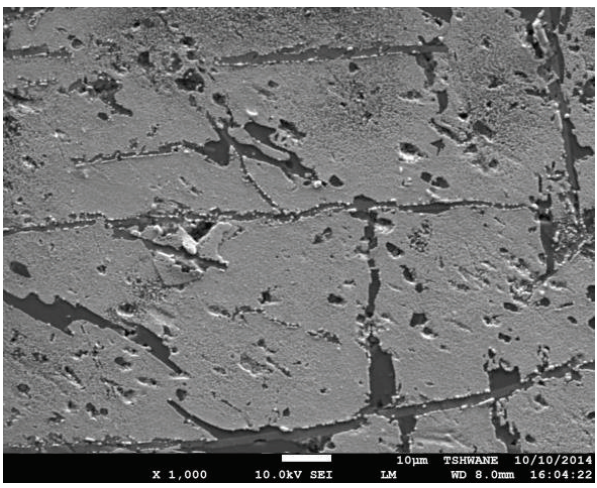

(c)

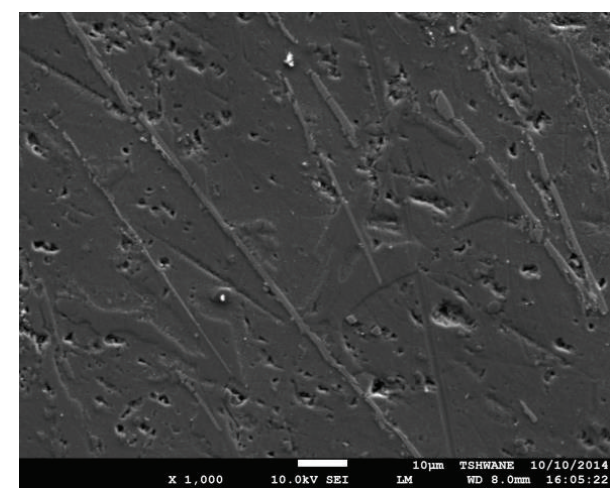

(b)

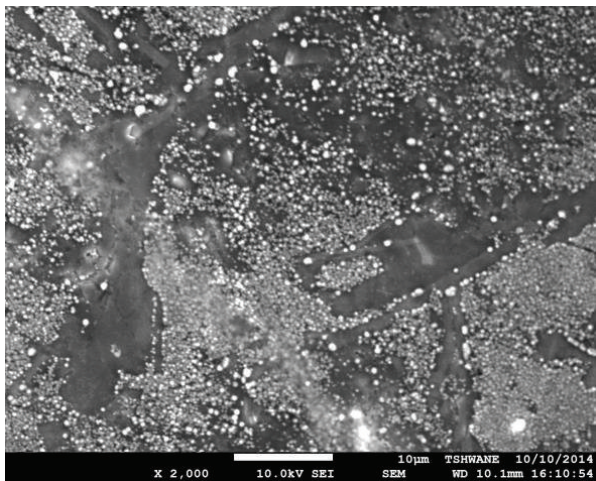

(d)

FIGURE 7: Microphotograph and SEM images showing EN deposition on (a) stainless steel at $85^{\circ} \mathrm{C}$ and $\mathrm{pH}=5.1$ without $\mathrm{pH}$ regulator and $1200 \mu \mathrm{m}$ grit polished substrates at (b) $\mathrm{pH}$ (5.2), (c) $\mathrm{pH}$ (5.3), and (d) $\mathrm{pH}(5.4) \mathrm{NaOH}$ regulated at $80^{\circ} \mathrm{C}$.

where $x$ is solution $\mathrm{pH}, 9.0 \leq x \geq 11.5$, and $M_{n 3}$ is the electroless nickel deposition per unit area with respect to plating solution $\mathrm{pH}$ on CAA coins in alkaline sodium hypophosphite reduced bath. The amount of deposition on the CAA varies with the increasing solution $\mathrm{pH}$ in which a range of $0.000252-0.000343 \mathrm{~g} / \mathrm{mm}^{2} \mathrm{EN}$ film depositions were obtained.

In summary, Figure 6 compares the amount of EN deposition on CAA substrates in acidic and alkaline sodium hypophosphite reduced plating baths. The study shows that the EN deposition per unit area and the EN film quality such as brightness are controlled by the plating solution $\mathrm{pH}$ on the CAA surfaces.

The metallurgical and surface properties that characterised the cast samples used in the present study have been discussed by the authors $[41,42]$. The present results also give further and better appreciation to the effective protective application of EN to solving or reducing the wear and corrosion of the cast aluminium alloy sample $[43,44]$.
It gives room to compare the similarities and the differences in the electroless nickel plating properties of the cast test samples available in the previous reports by Ajibola et al. [10].

\section{Conclusions}

The EDX data inferred that EN deposition increased with the immersion time that correlates with the experimentally derived weight gain measurement. Maximum values of $4.34 \times 10^{-04} \mathrm{~g} / \mathrm{mm}^{2}$ and EN deposition rate of $4.34 \times$ $10^{-05} \mathrm{~g} / \mathrm{mm}^{2} / \mathrm{min}$ were obtained within the increasing 1 to 10 minutes plating time frame.

The EN plating requires a high amount of energy for the autocatalytic reaction to be effective since the kinetics of the reaction is temperature controlled. The range of EN deposition on CAA is at $1.79 \times 10^{-05}$ to $2.31 \times 10^{-05}\left(\mathrm{~g} / \mathrm{mm}^{2} / \mathrm{min}\right)$ at $85^{\circ} \mathrm{C}$. The film properties (adhesion and brightness) are dependent on the bath temperature, and the best of the 


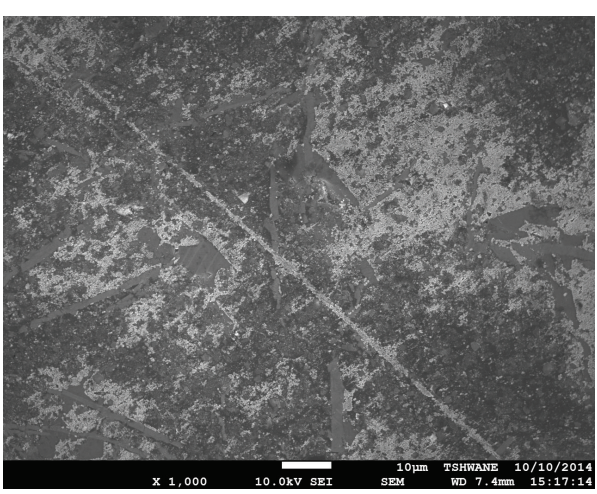

(a)

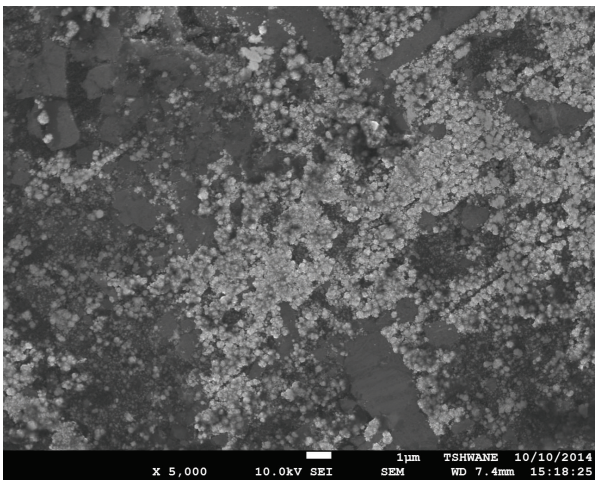

(c)

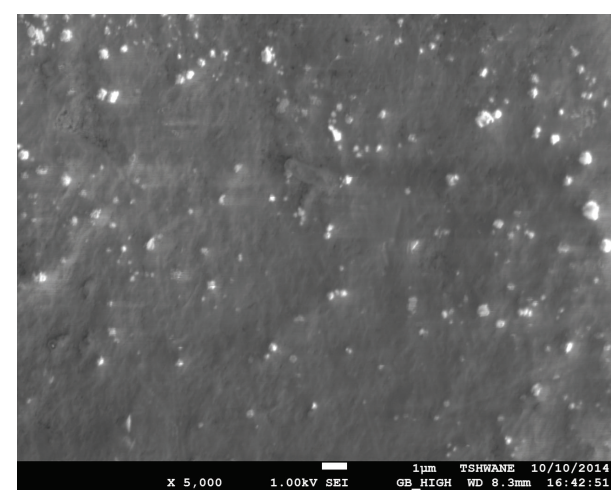

(b)

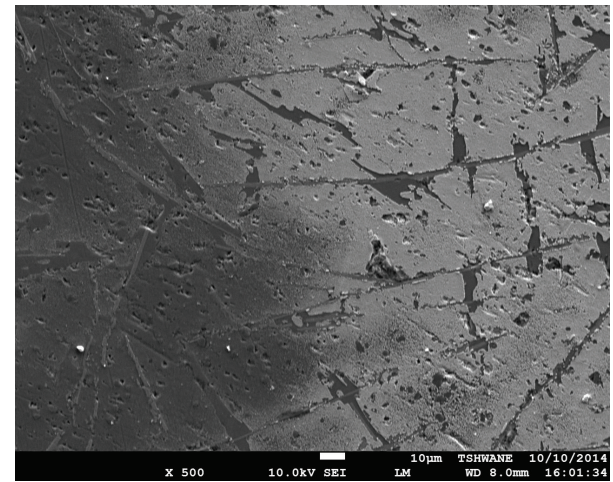

(d)

Figure 8: Micrographs showing deposits of (a) EN flakes on CAA surfaces at $\mathrm{pH}=9.5$, bright, metallic EN plating at (b) $\mathrm{pH}=10.5$, (c) $\mathrm{pH}=$ 11.0 , and (d) $\mathrm{EN}$ on plastic stirrer in $\mathrm{pH}=11.5 \mathrm{NH}_{4} \mathrm{OH}$ regulated baths at $85^{\circ} \mathrm{C}$.

adhesion of EN films on CAA was in most cases obtained at temperatures higher than $80^{\circ} \mathrm{C}$.

The reaction is aggressive, hence the significant need to zincate the CAA substrate prior to the immersion. The film properties (adhesion and brightness) are dependent on the $\mathrm{pH}$ of the plating solution. The best sets of electroless nickel plating were obtained at solution $\mathrm{pH}$ operated at 5.1-5.2 and 10.5-11.5 for acid and alkaline sodium hypophosphite reduced bath, respectively, being operated at $85^{\circ} \mathrm{C}$.

The study shows that the amount and the quality of EN film (morphology) are mainly dependent and controlled by the plating solution $\mathrm{pH}$ and the operating temperature at any corresponding time.

\section{Conflict of Interests}

The authors declare that there is no conflict of interests regarding the publication of this paper.

\section{Acknowledgments}

The authors highly appreciate the leadership of Electrochemical and Materials Characterization Research Laboratory of the TUT, Pretoria, South Africa, for all SEM/EDX analyses. The authors recognize the staff and management of the Premier Wings Engineering Services, Ado Ekiti, for providing the workshop services for the production and preparation of materials used for the study.

\section{References}

[1] Y. B. Chauhan, "An electroless plating-a review paper," International Journal for Scientific Research \& Development, vol. 2, no. 11, pp. 161-165, 2015.

[2] M. Schlesinger and M. Paunovic, Eds., Modern Electroplating, John Wiley \& Sons, 5th edition, 2010.

[3] C. K. Lee, "Corrosion and wear-corrosion resistance properties of electroless Ni-P coatings on GFRP composite in wind turbine blades," Surface and Coatings Technology, vol. 202, no. 19, pp. 4868-4874, 2008.

[4] P. Sahoo and S. K. Das, "Tribology of electroless nickel coatings-a review," Materials \& Design, vol. 32, no. 4, pp. 1760$1775,2011$.

[5] P. S. Kumar and P. K. Nair, "Structural transformations in electro-less Ni-P-B deposits," Plating and Surface Finishing, vol. 71, pp. 96-100, 1994.

[6] V. V. N. Reddy, B. Ramamoorthy, and P. K. Nair, "A study on the wear resistance of electroless Ni-P/Diamond composite coatings," Wear, vol. 239, no. 1, pp. 111-116, 2000.

[7] R. Rajendran, W. Sha, and R. Elansezhian, "Abrasive wear resistance of electroless Ni-P coated aluminium after post treatment," Surface and Coatings Technology, vol. 205, no. 3, pp. 766-772, 2010. 
[8] J. C. A. Batista, A. Matthews, and C. Godoy, "Micro-abrasive wear of PVD duplex and single-layered coatings," Surface and Coatings Technology, vol. 142-144, pp. 1137-1143, 2001.

[9] M. Hino, K. Murakami, M. Hiramatsu, K. Chen, A. Saijo, and T. Kanadani, "Effect of zincate treatment on adhesion of electroless Ni-P plated film for 2017 aluminum alloy," Materials Transactions, vol. 46, no. 10, pp. 2169-2175, 2005.

[10] O. O. Ajibola, D. T. Oloruntoba, and B. O. Adewuyi, "Effects of hard surface grinding and activation on electroless-nickel plating on cast aluminium alloy substrates," Journal of Coatings, vol. 2014, Article ID 841619, 10 pages, 2014.

[11] M. Hino, K. Murakami, Y. Mitooka, K. Muraoka, and T. Kanadani, "Effects of zincate treatment on adhesion of electroless Ni-P coating onto various Aluminum alloys," Transactions of Nonferrous Metals Society of China, vol. 19, no. 4, pp. 814-818, 2009.

[12] K. Azumi, M. Seo, and L. Nanis, "Changes in potential and weight of aluminium alloy during double zincate process," Journal of the Surface Finishing Society of Japan, vol. 47, no. 6, pp. 529-535, 1996.

[13] K. Tashiro, K. Chiba, Y. Fukuda, H. Nakao, and H. Honma, "Relationship between pretreatment and initial deposition in electroless nickel plating on Aluminum substrate," Journal of the Surface Finishing Society of Japan, vol. 45, no. 7, pp. 720-725, 1994.

[14] J. Hajdu and S. Zabrocky, "The future of electroless nickel," Metal Finishing, vol. 98, no. 5, pp. 42-46, 2000.

[15] Z. Abdel Hamid and M. T. Abou Elkhair, "Development of electroless nickel-phosphorous composite deposits for wear resistance of 6061 Aluminum alloy," Materials Letters, vol. 57, no. 3, pp. 720-726, 2002.

[16] X. G. Chen and J. Langlais, "Solidification behavior of AA6111 automotive alloy," Materials Science Forum, vol. 331-337, pp. 215-222, 2000.

[17] Y.-H. Tan, S.-L. Lee, and Y.-L. Line, "Effects of be and fe content on plane strain fracture toughness in A357 alloys," Metallurgical and Materials Transactions A, vol. 26, no. 11, pp. 2937-2945, 1995.

[18] M. Ravi, U. T. S. Pillai, B. C. Pai, A. D. Damodaran, and E. S. Dwarakadasa, "A study of the influence of mischmetal additions to ai-7si-0.3 mg (lm 25/356) alloy," Metallurgical and Materials Transactions A, vol. 27, no. 5, pp. 1283-1292, 1996.

[19] I. E. Ayoub, "Study of electroless Ni-P plating on stainless steel," Isotope and Radiation Research, vol. 41, no. 4, supplement 2, pp. 1551-1559, 2009.

[20] C.-L. Lee, L.-C. Kuo, Y.-C. Huang, and Y.-W. Yen, "Mesoporous, self-assembled palladium nanospheres: high efficiency activator for electroless nickel deposition," Electrochemistry Communications, vol. 8, no. 5, pp. 697-702, 2006.

[21] R. N. Duncan, "The metallurgical structure of electroless nickel deposits: effect of coating properties," Plating and Surface Finishing, vol. 83, no. 11, pp. 65-69, 1996.

[22] K.-L. Lin and J.-W. Hwang, "Effect of thiourea and lead acetate on the deposition of electroless nickel," Materials Chemistry and Physics, vol. 76, no. 2, pp. 204-211, 2002.

[23] M. I. Jafar, M. Broadhurst, and S. A. Ashton, "Some factors affecting corrosion. resistance of electroless nickel," British Corrosion Journal, vol. 31, pp. 239-240, 1996.

[24] M. A. Sánchez, L. A. Parra, O. A. Pérez, and O. De Rincón, "Electroless nickel coating for reinforcing steel in chloride contaminated concrete," Corrosion Reviews, vol. 19, no. 2, pp. 105-118, 2001.
[25] G. O. Mallory and B. J. Hajdu, Eds., Electroless Plating: Fundamentals and Applications, vol. 1, AESF, Orlando, Fla, USA, 1990.

[26] R. Ambat and W. Zhou, "Electroless nickel-plating on AZ91D magnesium alloy: effect of substrate microstructure and plating parameters," Surface and Coatings Technology, vol. 179, no. 2-3, pp. 124-134, 2004.

[27] S. K. Das and P. Sahoo, "Tribological characteristics of electroless Ni-B coating and optimization of coating parameters using Taguchi based grey relational analysis," Materials and Design, vol. 32, no. 4, pp. 2228-2238, 2011.

[28] P. Gadhari and P. Sahoo, "Effect of process parameters on microhardness of Ni-P- $\mathrm{Al}_{2} \mathrm{O}_{3}$ composite coatings," Procedia Materials Science, vol. 6, pp. 623-632, 2014.

[29] G. O. Mallory and J. B. Hajdu, Eds., Electroless PlatingFundamentals and Applications, American Electroplaters and Surface Finishers Society, 1990.

[30] A. S. Singh, V. K. Bajpai, and C. H. Solanki, "Effect of light on electroless nickel deposition for solar cell applications," Energy Procedia, vol. 54, pp. 763-770, 2014.

[31] O. O. Ajibola and B. O. Jimoh, "Aluminium recycling industries in Nigeria: entrepreneurship challenges and opportunities," in Proceedings of the 7th Engineering Forum, vol. 2, pp. 238-247, Ado Ekiti, Nigeria, November 2011.

[32] O. O. Ajibola, B. O. Adewuyi, and D. T. Oloruntoba, "Design and performance evaluation of wear test jig for aluminium alloy substrate in hydraulic fluid," in Proceedings of the 8th Engineering Forum, vol. 1, pp. 85-96, October 2012.

[33] O. O. Ajibola, B. O. Adewuyi, and D. T. Oloruntoba, "Wear behaviour of sand cast eutectic Al-Si alloy in hydraulic brake fluid," International Journal of Innovation and Applied Studies, vol. 6, no. 3, pp. 420-430, 2014.

[34] O. O. Ajibola, D. T. Oloruntoba, and B. O. Adewuyi, "Metallurgical study of cast aluminium alloy used in hydraulic master brake calliper," International Journal of Innovation and Scientific Research, vol. 8, no. 2, pp. 324-333, 2014.

[35] O. O. Ajibola, D. T. Oloruntoba, and B. O. Adewuyi, "Design and performance evaluation of wear test jig for aluminium alloy substrate in hydraulic fluid," in Proceedings of the Inaugural African Corrosion Congress and Exhibition (AfriCORR '14), Pretoria, South Africa, July 2014.

[36] S. Wang and W. Zhang, "Influence of heat treatment for coating of nickel plating on hollow glass beads," Physics Procedia, vol. 50, pp. 219-224, 2013.

[37] J. C. Rajaguru, C. Au, and M. Duke, "Study of electroless nickel plating on PerFactory ${ }^{\mathrm{TM}}$ rapid prototype model," Journal of Achievements in Materials and Manufacturing Engineering, vol. 55, no. 2, pp. 782-789, 2012.

[38] J. T. WinowlinJappes, Studies on electroless Ni-P and NiP/diamond composite coatings [Ph.D. thesis], Indian Institute of Technology Madras, Chennai, India, 2004.

[39] H. Pari, R. Raj, G. Pandiarajan, and E. Rasu, "Study on the performance of electroless nickel coating on aluminium for cylinder liners," Patent no. F2008-SC-015, 2008.

[40] R. C. Agarwala and V. Agarwala, "Electroless alloy/composite coatings: a review," Sadhana, vol. 28, no. 3-4, pp. 475-493, 2003.

[41] O. O. Ajibola and D. T. Oloruntoba, "Effect of MgFeSi inoculant on properties of Cast $6061 \mathrm{Al}$ Alloy for brake master piston application," Indian Journal of Materials Science, vol. 2015, Article ID 756219, 10 pages, 2015.

[42] O. O. Ajibola, D. T. Oloruntoba, and B. O. Adewuyi, "Effect of moulding sand permeability and pouring temperatures on 
properties of cast 6061 aluminum alloy," International Journal of Metals, In press.

[43] O. O. Ajibola and D. T. Oloruntoba, "Wear and corrosion of cast $\mathrm{Al}$ alloy piston with and without brake oil," Indian Journal of Materials Science, In press.

[44] O. O. Ajibola, D. T. Oloruntoba, and B. O. Adewuyi, "Design and performance evaluation of wear test jig for aluminium alloy substrate in hydraulic fluid," African Corrosion Journal, vol. 1, no. 1, pp. 40-45, 2014. 

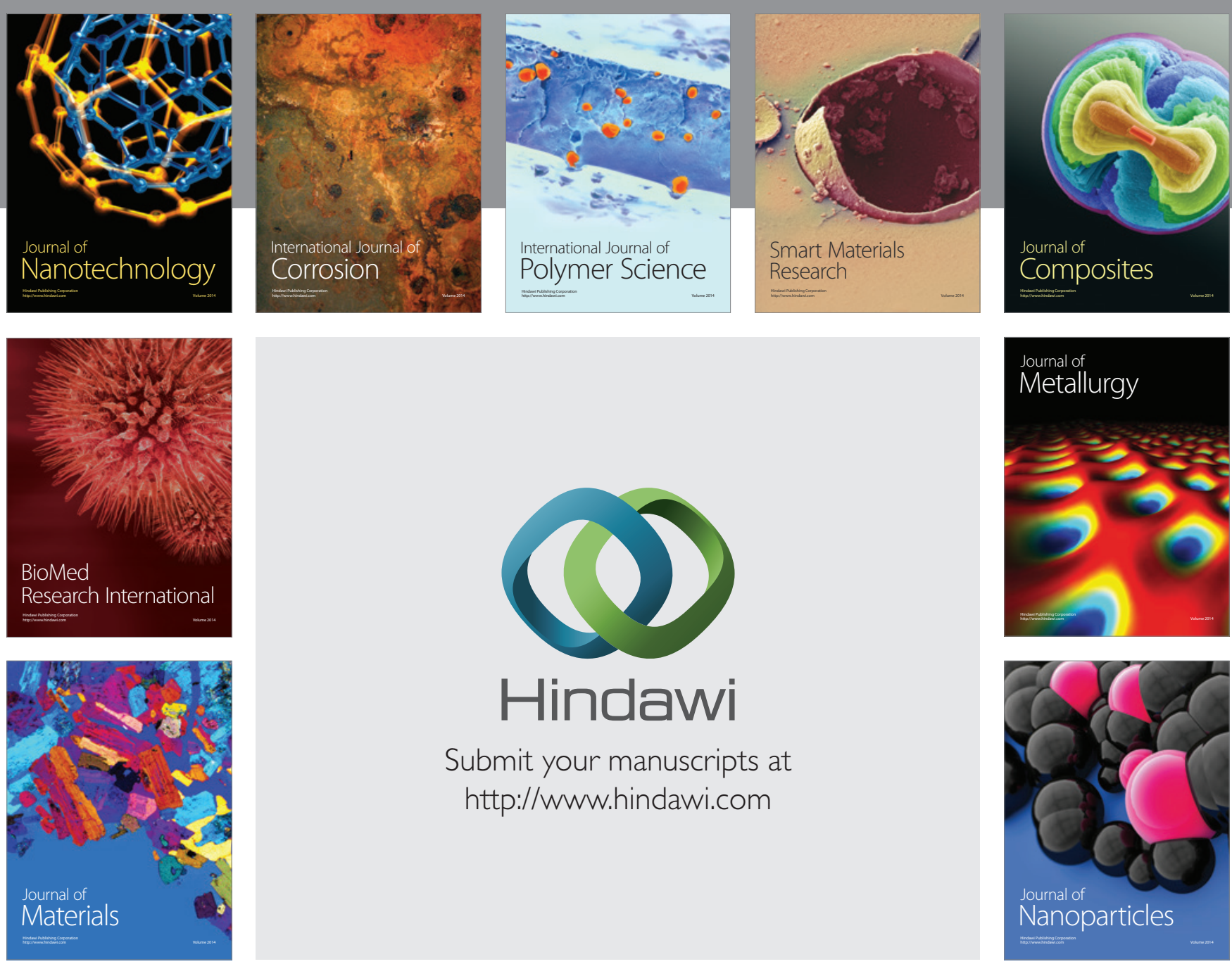

Submit your manuscripts at http://www.hindawi.com
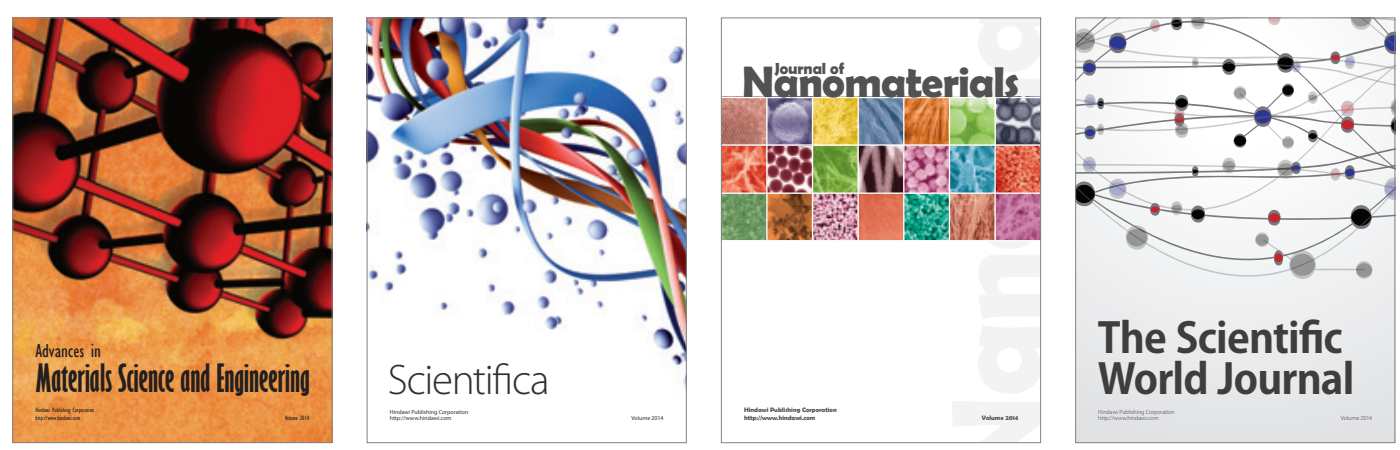

\section{The Scientific World Journal}
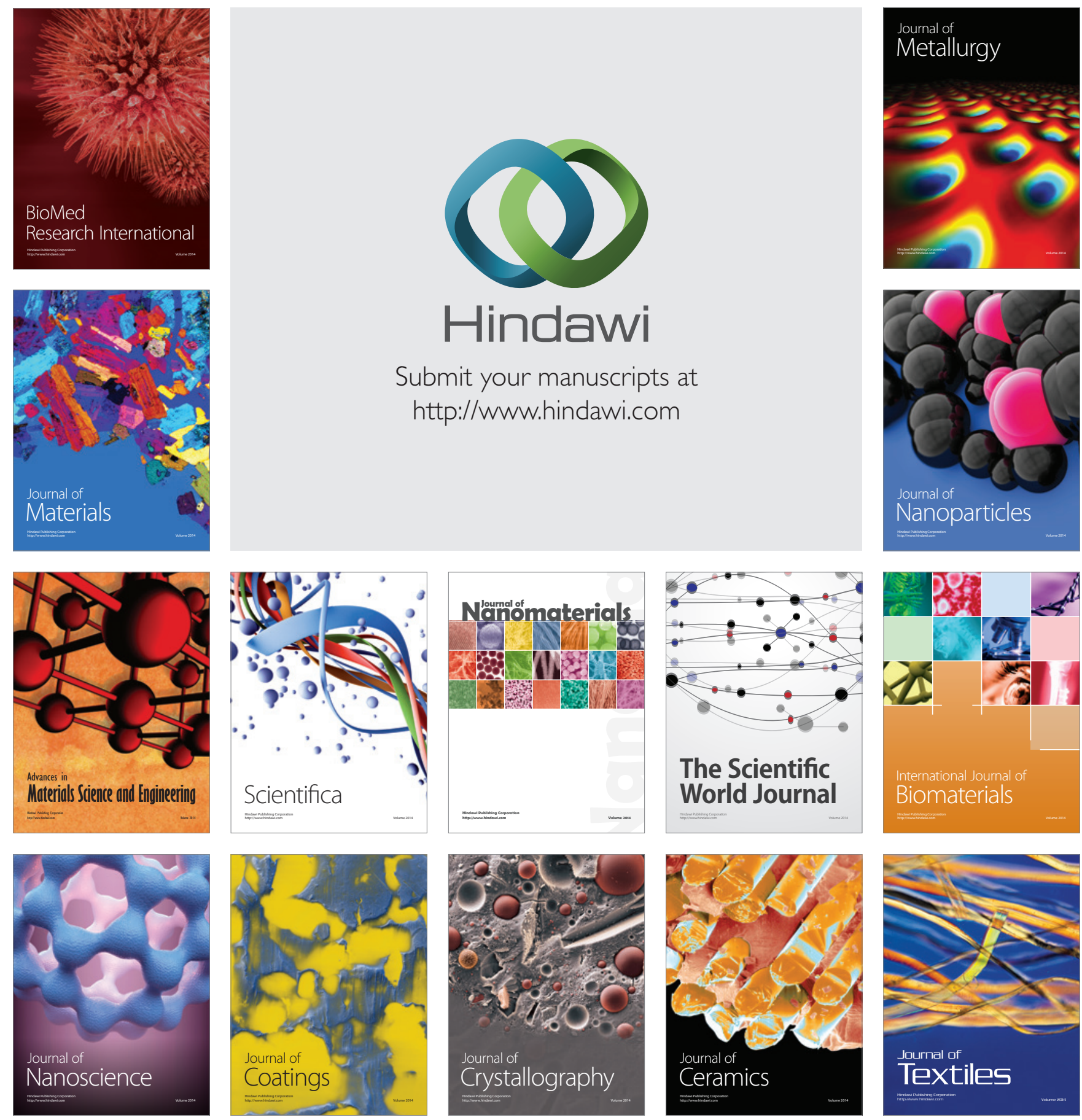